\title{
Exploring the inorganic composition of the Asian Tropopause Aerosol Layer using medium-duration balloon flights
}

\author{
Hazel Vernier ${ }^{1}$, Neeraj Rastogi ${ }^{2}$,Hongyu Liu ${ }^{3,4}$, Amit Kumar Pandit $^{3}$, Kris Bedka $^{4}$, Anil Patel ${ }^{2}$, \\ Madineni Venkat Ratnam ${ }^{5}$, Buduru Suneel Kumar ${ }^{6}$, Bo Zhang ${ }^{3}$, Harish Gadhavi², Frank \\ Wienhold $^{7}$, Gwenael Berthet ${ }^{1}$, Jean-Paul Vernier ${ }^{3,4}$ \\ 1. Laboratoire de Physique et Chimie de l'Environnement et de l'Espace (LPC2E), France \\ 2. Physical Research Laboratory, Ahmedabad, India \\ 3. National Institute of Aerospace, Hampton, VA, USA \\ 4. NASA Langley Research Center, Hampton, VA, USA \\ 5. National Atmospheric Research Laboratory, Gadanki, India \\ 6. TIFR Balloon Facility, Hyderabad, India \\ 7. ETH, Zürich, Switzerland \\ Correspondence to: hazel.vernier (hazel@cnrs-orleans.fr)
}

\begin{abstract}
Satellite observations have revealed an enhanced aerosol layer near the tropopause over Asia during the summer monsoon, called the Asian Tropopause Aerosol Layer (ATAL). In this work, aerosol particles in the ATAL were collected with a balloon-borne impactor near the tropopause region over India, using extended duration balloon flights, in summer 2017 and winter 2018. Their chemical composition was further investigated by quantitative analysis using offline ion chromatography. Nitrate $\left(\mathrm{NO}_{3}^{-}\right)$and nitrite $\left(\mathrm{NO}_{2}{ }^{-}\right)$were found to be the dominant ions in the collected aerosols with values ranging between $87-343 \mathrm{ng} / \mathrm{m}^{3}$ STP during the summer campaign. In contrast, sulfate $\left(\mathrm{SO}_{4}{ }^{2-}\right)$ levels were found above the detection limit $\left(>10 \mathrm{ng} / \mathrm{m}^{3}\right.$ STP) only in winter. In addition, we determined the origin of the air masses sampled during the
\end{abstract}


1 flights through analysis of back trajectories along with convective influence. The results obtained therein were put into a context of large-scale transport and aerosol distribution with GEOS-Chem chemical transport model simulations. The first flight of summer 2017 which sampled air mass within the Asian monsoon anticyclone (AMA), influenced by convection over Western China, was associated with particle size radius $(0.05-2 \mu \mathrm{m})$. In contrast, the second flight sampled air mass at the edge of the AMA associated with larger particle size radius $(>2 \mu \mathrm{m})$ with higher nitrite concentration. The sampled air masses in winter 2018 were likely affected by smoke from

8 the Pacific Northwest fire event in Canada, which occurred 7 months prior to our campaign,

9 leading to concentration enhancements of $\mathrm{SO}_{4}{ }^{2-}$ and $\mathrm{Ca}^{2+}$. Overall, our results suggest that nitrogen-containing particles represent a large fraction of aerosols populating the ATAL, in agreement with the results from aircraft measurements during the StratoClim campaign. Furthermore, GEOS-Chem model simulations suggest that lightning $\mathrm{NO}_{\mathrm{x}}$ emissions had a significant impact on the production of nitrate aerosols sampled during the summer 2017.

\section{Introduction}

1.1 Asian Summer Monsoon and the transport of pollution

Rapid economic growth in Asia over the past two decades have led to serious environmental threats on water and air qualities. Every winter, pollutants can be observed through satellites in the form of a grayish veil of particulate matter referred to as the Asian Brown Cloud (Ramanathan and 
1 Crutzen, 2003). Temperature inversion blocks dangerous life-threatening pollutants near the 2 ground such as particles with diameter less than 2.5 microns $\left(\mathrm{PM}_{2.5}\right)$ with levels up to 10 times higher than the World Health Organization recommendations. In summer, the Southwest Asian Monsoon (SAM) discharges polluted air over very long distances. About $20 \%$ of air masses in the tropical lower stratosphere have been in contact with air in the boundary layer in Asia according to trajectory calculations (Orbe et al., 2015). Polluted air masses transported from the boundary layer to higher altitudes are confined within the Asian Monsoon Anticyclone (AMA) (Ploeger et al., 2017). In the AMA, pollution is accumulated and is further dispersed over a large area of the Northern Hemisphere reaching longitudes from $10^{\circ}-140^{\circ} \mathrm{E}$, and latitudes from $10^{\circ}-40^{\circ} \mathrm{N}$ (Park et al., 2007; Randel et al., 2010; Ungermann et al., 2016). The air exported from the AMA influences the composition of the entire lowermost stratosphere of the Northern Hemisphere (Ploeger et al., 2017; Santee et al., 2017; Yu et al., 2017). Deep convective clouds represent conduits for air pollution to reach the Upper Troposphere and Lower Stratosphere (UTLS) region. Aerosols in the UTLS have longer residence times than those in the lower troposphere, influencing the chemistry of the atmosphere and the Earth's climate (Rasch et al., 2008). In addition, they also affect the concentration of chemical species through changes in photolysis rates and heterogenous reactions (Pitari et al., 2014). It has been further reported that aerosols in the UTLS can impact climate by altering properties of cirrus clouds via homogeneous or heterogeneous ice nucleation ( $\mathrm{Li}$ et al., 2005; Liu et al., 2009; Yin et al., 2012; Fadnavis et al., 2013).

A layer of aerosol enhancements observed by the Cloud-Aerosol Lidar and Pathfinder Satellite Observations (CALIPSO) and the Stratospheric Aerosol and Gas Experiment (SAGE) II (Vernier et al., 2011; Thomason and Vernier, 2013), also known as the Asian Tropopause Aerosol Layer (ATAL), coincide with the presence of enhanced trace gas pollutants (carbon monoxide (CO), hydrogen cyanide (HCN), etc.) in the UTLS region. Satellite and balloon-borne measurements (Vernier et al., 2011, 2015) confirmed the presence of ATAL at altitudes of 14-18 km, connected to the AMA. The positive trend in UTLS aerosols inferred from satellites observations since the late 90's may reflect the increasing influence of anthropogenic emissions on stratospheric aerosol levels. Indeed, global chemical transport model simulations suggest that sulfate, nitrate and organic aerosols produced from gas-phase precursors populates the UTLS region over Asia in various relative fractions during the summer monsoon (Brabec et al., 2012; Gu et al., 2016; Fairlie et al., 2020). 
2 The ATAL constitutes one of the most important sources of UTLS aerosols in the absence of 3 volcanic eruptions (Vernier et al., 2011). It has the potential to affect the Earth's radiative balance 4 (Vernier et al., 2015), stratospheric ozone chemistry, and the properties of cirrus clouds. For example, an increase of solid particle concentration relative to the liquid background aerosol levels could trigger heterogeneous freezing and the formation of cirrus clouds at a lower relative humidity with respect to ice (Cziczo et al., 2015; Wang et al., 2020). Model simulations suggest that the

8 ATAL represents $20 \%$ of the total column surface area density in the stratosphere of the Northern

9 Hemisphere (Yu et al., 2018) with potential halogen heterogeneous chemistry on aerosols that can affect ozone trends (Solomon et al., 2016). The types of aerosols populating the ATAL could affect those chemical processes. Finally, the presence of absorbing aerosols (e.g., soot) in the UTLS could shift the level of zero net radiative heating upward and enhance troposphere-to-stratosphere transport (Yu et al., 2015).

1.3 What is known about ATAL's composition?

The composition of the ATAL is a very active research topic. Energy-dispersive X-ray analysis (EDX) of aerosols sampled near 10-12 km onboard commercial aircraft as part of the Civil Aircraft for the Regular Investigation of the atmosphere Based on an Instrument Container (CARIBIC) program, at the bottom part of the ATAL, suggests a ratio between carbon and sulfur in the range 2-10 (Vernier et al., 2015). Aircraft Limb InfraRed measurements carried out during the StratoClim campaign in Nepal and India show the presence of ammonium nitrate in aerosol particles, validating satellite observations from the Cryogenic Infrared Spectrometers and Telescopes for the Atmosphere (CRISTA), and Michelson Interferometer for Passive Atmospheric Sounding MIPAS (Höpfner et al., 2019).

The aerosol particles in the ATAL are looked upon as an insignia of the presence of pollution in the monsoon circulation from large $\mathrm{SO}_{2}$ and $\mathrm{NO}_{\mathrm{x}}$ emissions in South and $\mathrm{SE}$ Asia. Human-induced biomass burning (Van der A et al., 2008), fossil fuel combustion (Ghude et al., 2009; Bouman et al., 2002), wildfires (Goode et al., 2000; Andrae and Merlet, 2001), and lightning (Martin et al., 2007) are the significant anthropogenic, and natural sources of $\mathrm{NO}_{\mathrm{x}}$. Soil biogenic emission of 
$1 \quad \mathrm{NO}_{\mathrm{x}}$ represents a large fraction of total $\mathrm{NO}_{\mathrm{x}}$ (Jalié et al., 2004). Reactive nitrogen is emitted from 2 the tropical soils by microbial processes as NO (Yienger and Levy, 1995; Conrad et al., 1996).

3 Investigations of the composition of the aerosol particles in the ATAL are exiguous, although preliminary data from balloon borne measurements indicate the presence of nitrate aerosol particles (Vernier et al., 2015, 2018). Recent in situ aerosol mass spectrometric measurements also reveal the presence of nitrate, ammonium and sulfate within the ATAL (Höpfner et al., 2016).

7 Here, we investigate the inorganic composition of the ATAL over India during the summer 8 monsoon and winter using a balloon-borne aerosol impactor system with offline Ion 9 Chromatography (IC) analysis. Section 2 describes the concept of the balloon experiment and the impactor system. The IC analysis of the samples collected during two balloon flights in 2017 and on the ground, as well as that of winter 2018 is described in Section 3. Section 4 compares those results obtained from balloon-borne measurements and satellite observations. Finally, the origin of the air masses sampled during those flights is assessed in Section 5 through back-trajectory analysis combined with convective proxies. The GEOS-Chem model simulations are presented in Section 6 to put the measurements in a context of regional aerosol transport and distribution, followed by summary and conclusions in Section 7 .

\section{Balloon flights, instrumentation, and chemical analysis approach}

\subsection{Rationale for the experiment}

Contingent on measurements during the 2015 Balloon borne measurement campaigns of the Asian Tropopause Aerosol Layer (BATAL) campaign, a concentration of 20 particle/ $\mathrm{cm}^{3}$ was found near the tropopause for aerosol radius greater than $75 \mathrm{~nm}$ (Vernier et al., 2018). It translates into a mass concentration of $40 \mathrm{ng} / \mathrm{m}^{3}$ assuming that the aerosols were liquid sulfate droplets. During that time, the lower detection limit for the IC instrument at NASA Langley Research Center was around 20 $\mathrm{ng} / \mathrm{m}^{3}$. In order to reach the detection limit of sulfate aerosols, one would need to sample at least $0.5 \mathrm{~m}^{3}$ assuming the sulfate concentration above. Based upon those results and weight limitations, we decided to use an impactor with a flow rate of $7 \mathrm{lpm}$ which would need to float in the UTLS region for several hours to sample sufficient volume of air $\left(2\right.$ hours of sampling $\left.=0.84 \mathrm{~m}^{3}\right)$.

\subsection{Balloon experiment}


1 We used zero-pressure plastic balloons to achieve a float near the tropopause and sample enough aerosols to reach the detection limit of the IC. The Tata Institute of Fundamental Research Balloon Facility (TIFR-BF) in Hyderabad, India provided the infrastructure to conduct the experiment. 300 to $500 \mathrm{~m}^{3}$ polyethylene balloons manufactured by TIFR were used for the Zero-Pressure flights (ZF) to carry a communication/control package developed by TIFR, a science module including a meteorological radiosonde, a Compact Optical Backscatter and Aerosol Detector (COBALD) (Vernier et al., 2015; Yu et al., 2017), an aerosol impactor, and a ballast module at the end of the flight train. A schematic diagram shown in Fig.1 (top panel) describes a typical balloon flight. During the ascent, atmospheric pressure decreases allowing gas inside the balloon to occupy a large space (stage 2). The equilibrium point is reached when the hydrogen escapes from the side escape tubes attached at the bottom of the balloon, until the inside pressure equals the outside pressure (stage 3 ) leading to the pressure differential to 0 (zero-pressure balloon). The float altitude depends upon the volume of the balloon, the density of gas, as well as the total weight of the system following simple Archimedes principle. Extreme cold temperatures near the tropopause affect the float due to radiative cooling, leading to a reduction of the buoyancy force, which entrain the descent of the system (stage 4). To counterbalance this effect, ballast shots are released from a container to reduce the total weight (stage 5) leading to the ascent of the balloon.

\subsection{Balloon-borne Aerosol Impactor}

We developed the Balloon-borne Aerosol Impactor (BAI) for the ZF flights. This aerosol sampler is comprised of a 4-stage impactor, a vacuum pump, a volumetric flow controller, and a RaspberryPI based controller connected to a meteorological sonde. The mechanical part of the impactor was designed by California Measurements, Inc. and is based upon the principle of inertia, where the flow and the instrument dimension determine the size cutoff at different stages. The size cutoff in radius for the 4 stages ( $\mathrm{S} 1, \mathrm{~S} 2, \mathrm{~S} 3$ and $\mathrm{S} 4$ ) of the impactor is $2,0.5,0.15$ and $0.05 \mu \mathrm{m}$ at $7 \mathrm{lpm}$. The pump is controlled electronically based on pressure measurements from the meteorological sonde. Our objective is to sample aerosols within the ATAL region, to achieve this the pump was switched on below $150 \mathrm{hPa}(\sim 14 \mathrm{~km})$ and switched off above $70 \mathrm{hPa}(\sim 18 \mathrm{~km})$.

In 2017, we conducted a series of balloon flights using the BAI together with a COBALD sonde for aerosol backscatter measurements of cloud and aerosol layers encountered by the BAI. The time-height evolution of the $3 \mathrm{ZFs}$ is shown in Fig.1 (bottom). The maximum flight duration was 
obtained through ZF3 with a float time of nearly $2 \mathrm{~h} 50 \mathrm{~min}$ above $150 \mathrm{hPa}$ and below $70 \mathrm{hPa}$. The oscillation of the balloon trajectories is due to the cooling of the gas inside the balloon and subsequent release of ballast to regain higher altitudes. The BAI was preserved in a foam box containing dry ice, during transportation to TIFR where the filters were immediately unloaded and stored in $47 \mathrm{~mm}$ Petri dishes which were frozen at $-24^{\circ} \mathrm{C}$ until further analysis at Physical Research Laboratory, Ahmedabad, India. Fig. 2 represents the time evolution of altitude, temperature, and relative humidity inside the box containing the impactor where the different phases of the experiment are mentioned.

\subsection{Analysis of major ions in aerosol samples}

Aerosol samples were extracted in deionized water (Milli-Q, specific resistance $\geq 18.2 \mathrm{M} \Omega$. $\mathrm{cm}$ ) in sterile polypropylene vials for 30 minutes (3 intervals of 10 minutes each) using ultrasonication. The extract was further analyzed for water-soluble inorganic species (WSIS, such as $\mathrm{Na}^{+}, \mathrm{K}^{+}, \mathrm{Mg}^{2+}, \mathrm{Ca}^{2+}, \mathrm{NH}_{4}{ }^{+}, \mathrm{Cl}^{-}, \mathrm{NO}_{2}{ }^{-}, \mathrm{NO}_{3}{ }^{-}$, and $\mathrm{SO}_{4}{ }^{2-}$ ) using an ion chromatograph (IC modelDionex ICS-5000 DC-5). For calibration, 1000 mg/L stock solution of each cation (using Merck high purity analytical grade $\mathrm{NaNO}_{2},\left(\mathrm{NH}_{4}\right)_{2} \mathrm{SO}_{4}, \mathrm{KNO}_{3}, \mathrm{CaCl}_{2} \cdot 2 \mathrm{H}_{2} \mathrm{O}$, and $\mathrm{Mg}$ metal) were prepared. In addition, mixed standards were prepared by diluting stock solutions in polypropylene vials, thus satisfying the primary requirement of instrument calibration for cations. Similarly, anion multi-element standard-II (1000 mg/L in $\mathrm{H}_{2} \mathrm{O}$, HC 409399, Merck) was diluted subsequently as instrument calibration for anions. Post extraction, the extract of each sample was then separated and eluted in the cation column (DIONEX IonPac ${ }^{\mathrm{TM}} \mathrm{SC} 16,5 \times 250 \mathrm{~mm}$ ), and anion column (DIONEX Ion Pac ${ }^{\mathrm{TM}}$ AS23, $4 \times 250 \mathrm{~mm}$ ) via the interaction with the mobile phases, i.e., $30 \mathrm{mM}$ methyl sulphonic acid (MSA) for cation and a mixture of $4.5 \mathrm{mM}$ carbonate $+0.8 \mathrm{mM}$ bi-carbonate solutions for anions. The quantification of each ion was then performed using the conductivity detector. Several blanks were also analyzed in the same way as the sample, and blank corrected from ionic concentrations are reported. As the concentrations of different species were too low in UTLS aerosol samples, only those values which were at least two times higher than their respective blanks are reported. More than $50 \%$ of samples were repeated for the reproducibility and found to vary between 2 to $20 \%$ for all the analyzed ions. To validate the analysis, Dionex six cation-I standard (product number 040187) and Dionex seven anion standard-II (Part \#57590) were diluted and checked in the respective cation and anion calibration curves which were found within $\pm 10 \%$ relative standard deviation (RSD). 


\section{Results of IC analysis}

3 Figure 3 shows the concentration of ions from ground (GND), and two ZF2, and ZF3 flight samples

4 collected during the summer 2017 campaign, in comparison with the only flight results of the winter 2018 campaign (ZF Winter). In GND samples, $\mathrm{Na}^{+}$and $\mathrm{Ca}^{2+}$ cations are seen on $\mathrm{S} 1$ and S2 with corresponding anions $\left(\mathrm{NO}_{3}{ }^{-}, \mathrm{SO}_{4}{ }^{2-}\right.$, and $\left.\mathrm{NO}_{2}{ }^{-}\right)$co-existing at the same stage. High $\mathrm{NH}_{4}{ }^{+}$is observed only on S3 with a concentration of $212 \mathrm{ng} / \mathrm{m}^{3}$ STP. $\mathrm{K}^{+}$was also seen on S3 with a concentration of $26 \mathrm{ng} / \mathrm{m}^{3} \mathrm{STP}$ (fine mode) that could have originated from biomass burning. City pollution from Hyderabad is likely the source of those aerosols observed on the GND filters. Flight ZF2 and ZF3 show significant amounts of $\mathrm{NO}_{3}{ }^{-}$and $\mathrm{NO}_{2}{ }^{-}\left(87-343 \mathrm{ng} / \mathrm{m}^{3} \mathrm{STP}\right)$ with traceable amounts of proxies for mineral dust $\left(\mathrm{Ca}^{2+}\right)$ and biomass burning $\left(\mathrm{K}^{+}\right)$. Other species were below 5 (for cations) to 10 (for anions) $\mathrm{ng} / \mathrm{m}^{3} \mathrm{STP}$, the detection limit of the IC instrument for our analytical setup. Charge balance was not achieved due to higher negative charge mainly from $\mathrm{NO}_{3}{ }^{-}$and $\mathrm{NO}_{2}{ }^{-}$ than the positive charge mainly from $\mathrm{NH}_{4}{ }^{+}, \mathrm{Ca}_{2}{ }^{+}$, and $\mathrm{K}^{+}$(Fig. 3), implying the existence of $\mathrm{NO}_{3}{ }^{-}$ and $\mathrm{NO}_{2}{ }^{-}$in forms rather than salt. For instance, nitric acid trihydrate (NAT, $\mathrm{HNO}_{3} \cdot 3 \mathrm{H}_{2} \mathrm{O}$ ) could be another aerosol cluster in which $\mathrm{NO}_{3}{ }^{-}$may be present in the tropical UTLS (Voigt et al., 2000). However, recent measurements from StratoClim campaign show that solid ammonium nitrate dominates the aerosol population of the ATAL with concentration up to $1.5 \mu \mathrm{g} / \mathrm{m}^{3}$ during summer (Hopfner et al., 2019). In contrast, we did not find a significant amount of ammonium in our ZF flight samples during the summer, but did find the same in the flight samples of winter (Fig. 3). Overall, the concentration of nitrate $\left(80-100 \mathrm{ng} / \mathrm{m}^{3} \mathrm{STP}\right)$ found on both flights seems to be lower than the levels observed during StratoClim (Hopfner et al., 2019). In the only successful flight during the winter $2018, \mathrm{Na}^{+}$and $\mathrm{K}^{+}$were almost inexistent. In comparison, the proxy of mineral dust $\left(\mathrm{Ca}^{2+}\right)$ was present on all four stages with traceable amounts, and could be associated with $\mathrm{SO}_{4}{ }^{2-}$ which was also found on all 4 stages (Fig. 3 Bottom).

Balloon-borne and aircraft sampling techniques have been used since the early 70's to study the composition of aerosols in the UTLS region (Lazarus et al., 1970). While sulfate tends to be stable enough to be collected and further analyzed without major chemical transformation, other nitratecontaining particles can be more unstable. $\mathrm{NO}_{3}{ }^{-}$salts apart from $\mathrm{NH}_{4} \mathrm{NO}_{3}$ are not significantly volatile after sampling (Newman et al., 1993). However, the dissociation of $\mathrm{NH}_{4} \mathrm{NO}_{3}$ into gas- 
1 (Seinfeld et al., 1982; Lightstone et al., 2000), leading to a significant loss of particulate nitrate

2 (PN). Between payload descent, sample recovery, and transportation, the observed temperature stayed below $35^{\circ} \mathrm{C}$ at $65 \%$ RH (Fig. 2), indicating that there was likelihood of the dissociation of $\mathrm{NH}_{4} \mathrm{NO}_{3}$ between recovery and transportation. The slight retention of $\mathrm{HNO}_{3}$ (gas) on PTFE filter could represent a significant source of particulate nitrate on filters at low concentration and was used in the past to estimate stratospheric $\mathrm{HNO}_{3}$ (Lazarus et al., 1970).

\section{COBALD and CALIOP backscatter measurements during ZF2}

ZF2 was launched to be collocated in space and time (within $20 \mathrm{~km}$ and $1 \mathrm{~h}$ ) with satellite observations from the CALIOP lidar onboard the CALIPSO satellite. Fig. 4 (Top) shows Scattering Ratio (SR) and Color Index (CI) profiles from COBALD (470 nm and $940 \mathrm{~nm}$ ) together with CALIOP SR and Volume Depolarization profiles at $532 \mathrm{~nm}$. The CI and both balloon and satellite observations show a layer between 13.5 and $16 \mathrm{~km}$ with high depolarization (CALIOP) and high color ratio (COBALD), likely made of aspherical particles. ZF2 flight floated near 16-17 $\mathrm{km}$ for more than $2 \mathrm{~h}$ (Fig.1, bottom). The time series (Fig.4, bottom) indicate that the measurements took place above $150 \mathrm{hPa}$ (43 min after takeoff), pressure threshold below which the pump connected to the impactor was switched on. In the thin ice cloud, the pump was on for nearly $16 \mathrm{~min}$. while most of the sampling was done for more than $1 \mathrm{~h}$ in a cloud-free region enhanced with aerosols above.

\section{Convective influence}

16-year climatological assessment of cirrus clouds, their microphysical, and optical properties were observed using a ground-based lidar over Gadanki, India (Pandit et al., 2015). When compared with those obtained by CALIOP, the observations showed the presence of cirrus clouds of geometrical thickness less than $2 \mathrm{~km}$. Moreover, the increasing fraction of sub-visible cirrus clouds between 1998-2003 probably modified on the temperature and the water vapor budget in the Tropical Tropopause Layer (Pandit et al., 2015). To study the impact of convection on our measurements, we calculate back-trajectories from ZF2 and ZF3 using the Langley Trajectory Model (LaTM) driven by GEOS-5 winds (Fairlie et al., 2014) and locate the intersection with anvils and deep convective clouds observed through Cloud Top Brightness Temperature from the HIMAWARI- 8 satellite (Vernier et al., 2018). Figure 5 shows the position of those 5-day back- 
1 trajectories (black lines) and deep convection influence (red dots). Air sampled during ZF2 on $15^{\text {th }}$ August 2017 travelled along two branches influenced by convection over southern/eastern China and western China, respectively. Air masses sampled by ZF3 originated from convection over Laos, Myanmar, the Bay of Bengal, and possibly local convection over the Indian Eastern Shore close to the measurement location.

\section{Comparison with GEOS-Chem simulations}

We conduct GEOS-Chem model simulations to put our observations in a context of large-scale transport and distribution of atmospheric composition. GEOS-Chem is a state-of-the-art global 3$\mathrm{D}$ chemical transport model that includes fully coupled ozone- $\mathrm{NO}_{\mathrm{x}}-\mathrm{VOC}$-aerosol chemistry for both troposphere and stratosphere (Bey et al., 2001; Park et al., 2004; Eastham et al., 2014). We use here the model version 11-01 (http://wiki.seas.harvard.edu/geos-chem/index.php/GEOSChem_v11-01). A previous version of the model was used to study the origins of aerosols in the ATAL by Gu et al. (2016) and Fairlie et al. (2020). The model simulates black carbon (Park et al., 2003), primary and secondary organic aerosols (Pyle et al., 2010), sulfate-nitrate-ammonium aerosols (Park et al., 2004), mineral dust (Fairlie et al., 2007; Ridley et al., 2014), and sea salt (Jaegle et al., 2011), treated as an external mixture. Anthropogenic emissions use the EDGAR database (Olivier \& Berdowski, 2001), with regional options, including the MIX inventory over East Asia (Li et al., 2014) and the EPA/NEI 2011 inventory over North America (Travis et al., 2016). Biofuel emissions are from Yevich and Logan (2003). Carbonaceous aerosol emissions are provided by Bond et al. (2007). Biogenic emissions are calculated by the MEGAN model (Guenther et al., 2012). Biomass burning emissions use the Quick-Fire Emissions Dataset (QFED; Darmenov \& da Silva, 2015). Lightning $\mathrm{NO}_{\mathrm{x}}$ emissions $\left(\mathrm{LNO}_{\mathrm{x}}\right)$ are as described by Murray et al. (2012) and match the Lightning Imaging Sensor and the Optical Transient Detector (LIS/OTD) climatological observations of lightning flashes. Volcanic $\mathrm{SO}_{2}$ emissions are provided by the AeroCom project (data available from www.geos-chem.org). The model simulations are driven by the Modern-Era Retrospective analysis for Research and Applications (MERRA-2) reanalysis from the NASA Global Modeling and Assimilation Office (Gelaro et al., 2017). For computational efficiency, MERRA-2 fields have been mapped from the native grid to $2.5^{\circ}$ by $2^{\circ}$ horizontal resolution for input to GEOS-Chem. Further, we used the simulations with 
1 and without lightning $\mathrm{NO}_{\mathrm{x}}$ emissions to understand the contribution of lightning to the formation of nitrate aerosol. In situ chemical analysis are compared with GEOS-Chem simulations. Fig. 6 shows the maps of $4 \mathrm{CO}$, nitrate, sulfate, and black carbon (BC) aerosol concentrations averaged over 100-150 hPa at 522 UTC for Aug. $15^{\text {th }}$ and $21^{\text {st }}$, respectively, during ZF2 and ZF3 flights (white dots on the map). 6 On Aug. $15^{\text {th }} \mathrm{CO}, \mathrm{BC}$ and nitrate aerosol concentrations are enhanced over West China, Nepal and 7 northeastern India with the center of the anticyclone positioned over West China. Measurements made during ZF2 were obtained from air masses with enhanced $\mathrm{CO}, \mathrm{BC}$ and nitrate as suggested 9 by the model. On the contrary on Aug. $21^{\text {st }}$ during ZF3, the position of the anticyclone was shifted to the east and the flight apparently sampled air at the edge of the anticyclone where $\mathrm{CO}, \mathrm{BC}$ and nitrate are significantly lower. The simulated nitrate concentrations near the location of ZF2 and ZF3 is spatially inhomogeneous with variations between 30 and $2700 \mathrm{ng} / \mathrm{m} 3$ across South India. Figure 7 shows the time series of model 3-hourly CO, sulfate and nitrate concentrations averaged over 100-150hPa within the model grid-point where Hyderabad is located during August 2017. The measured nitrate concentration during ZF2 and ZF3 near $\sim 100 \mathrm{ng} / \mathrm{m} 3$ are within the ranges of values simulated within $24 \mathrm{~h}$ of the observations. The results of the GEOS-chem model simulation signifies that lightning $\mathrm{NO}_{\mathrm{x}}$ could significantly (up to $\sim 75 \%$ on August 10 th) contribute to the formation of nitrates during certain time periods. The lifetime of $\mathrm{NO}_{\mathrm{x}}$ is approximately $3 \mathrm{~h}$ in the region of the outflow of thunderstorms due to the production of methyl proxy nitrate and alkyl, and multifunctional nitrates. The $\mathrm{NO}_{\mathrm{x}}$ lifetime is believed to increase downwind from the outflow. Also shown in Fig.7 are nitrate concentrations attributed to lightning as determined by the difference between simulations with and without lightning NOx emissions. ZF2 and ZF3 occurred during a period where the levels of nitrate were relatively small ( $\left.<100 \mathrm{ng} / \mathrm{m}^{3} \mathrm{STP}\right)$, with minimal influence of lightning $\mathrm{NO}_{\mathrm{x}}$ emissions. Nevertheless, $\mathrm{CO}$ levels are slightly higher during ZF2 (80 ppbv) than ZF3 (60 ppbv), indicating that measurements made during ZF2 may have been more influenced by pollution. The latter is also reflected by the higher BC levels during ZF2 in the model.

We extracted $\mathrm{CO}$, nitrate and sulfate concentration from the GEOS-Chem simulation along the calculated trajectories initialized from ZF2 and ZF3 measurement locations in Fig. 8. The lines are colored according to the balloon GPS altitudes which are used to initialize the trajectory model. Fig.5 shows that GEOS-chem could simulate convective activities reaching levels 
between 14-15 km as confirmed by cloud top heights (black circle) derived from HIMAWARI-8 crossed by trajectories originating from the troposphere for both ZF2 and ZF3. ZF2 was influenced by convective activities over Western China while ZF3 sampled air masses originated from convection in SE Asia (Myanmar, Laos). CO levels with initial altitudes near 14-15 km (green color) for ZF2 are shown to decrease from $120 \mathrm{ng} / \mathrm{m} 3$ to $80 \mathrm{ng} / \mathrm{m} 3$ along the backtrajectories confirming the influence of Chinese pollution and its progressive dilution. At the

7 same initial altitudes, The CO levels along ZF3 back-trajectories are significantly lower near 50-

$8 \quad 80 \mathrm{ng} / \mathrm{m} 3$ possibly indicating minimal impacts of polluted sources. Sulfate concentrations are much higher (100-200 ng/m3) for air parcels initialized near 16-17 km for ZF2 and ZF3 likely indicating stratospheric sources while air parcels near 14-15 km show levels below $100 \mathrm{ng} / \mathrm{m} 3$. We note that sulfate along the trajectories influenced by Chinese pollution during ZF2 increase significantly $50 \mathrm{~h}$ before our measurements which could indicate the formation of sulfate aerosol from $\mathrm{SO}$. The levels of NO3 show significant variability along the trajectories for both cases but more pronounced in ZF3 with levels above $400 \mathrm{ng} / \mathrm{m} 3$ emphasizing again the likely importance of LNOx in the production of nitrate aerosols.

\section{Summary and Conclusions}

The chemical composition of the ATAL has been investigated using offline IC analysis of aerosol impacted samples collected onboard the zero-pressure balloon flights as part of the BATAL campaigns. The measurements of the 2017 summer campaign indicate the dominating presence of nitrate and nitrite aerosols with concentrations between 88 and $374 \mathrm{ng} / \mathrm{m}^{3} \mathrm{STP}$. Our first flight (ZF2) on $15^{\text {th }}$ August 2017, occurred within the AMA and thus sampled air masses therein. In situ measurements revealed the presence of $\mathrm{NO}_{3}{ }^{-}$, and $\mathrm{NO}_{2}{ }^{-}$aerosols $\left(60-200 \mathrm{ng} / \mathrm{m}^{3} \mathrm{STP}\right)$ of size ranging between $0.05-2 \mu \mathrm{m}$. The second flight (ZF3) on $21^{\text {st }}$ August 2017, however, occurred at the edge of the anticyclone and subsequent in situ measurements revealed the presence of larger particle size $\mathrm{NO}_{3}{ }^{-}$and $\mathrm{NO}_{2}{ }^{-}$aerosols at higher concentrations $\left(87.3-343 \mathrm{ng} / \mathrm{m}^{3} \mathrm{STP}\right)$. Throughout the flights during the 2017 summer campaign, sulfate aerosol remained below the detection limit of the system $\left(10 \mathrm{ng} / \mathrm{m}^{3} \mathrm{STP}\right)$ much lower than the results from the GEOS-Chem model simulation $\left(80-120 \mathrm{ng} / \mathrm{m}^{3} \mathrm{STP}\right)$ which may suggest that sulfate removal is insufficient in the model. Unlike 
1 the summer, $\mathrm{Ca}^{2+}$ and $\mathrm{SO}_{4}{ }^{2-}$ were found on all four stages in sizes ranging between $0.2-0.05 \mu \mathrm{m}$ together with traces of NH4+ which couldn't be quantified in the winter campaign. The winter flight sampled residual from the 2017 Canadian wildfires which affected stratospheric aerosol loadings for several months.

We study the influence of convection on those measurements using back trajectory calculations collocated with geostationary satellite observations. We show that ZF2 and ZF3 were influenced by convection over Western China, the Bay of Bengal as well as Myanmar, Thailand, and Laos.

While the model seems to represent convection in the upper troposphere (14-15 km) with the rapid ascension of air parcels, the model ability to simulate convective influence at higher altitudes seem to be limited.

We used the GEOS-chem model simulations with and without lightning $\mathrm{NO}_{\mathrm{x}}$ emissions to understand the contribution of lightning to nitrate aerosol. The flights, ZF2 (Aug. 15 ${ }^{\text {th }}$ ) and ZF3 (Aug. $\left.21^{\text {st }}\right)$ occurred during a period where the levels of nitrate were relatively small $\left(<100 \mathrm{ng} / \mathrm{m}^{3}\right.$ STP), with minimal influence of lightning $\mathrm{NO}_{\mathrm{x}}$ in contrast with other periods largely affected by nitrate produced by LNOx. The chemical information extracted from GEOS-Chem along the trajectories indicates that ZF2 was influenced by Chinese pollutions associated with high levels of $\mathrm{CO}$ where smaller nitrate particles were found which could also indicate the influence of new particle formation.

Data availability. We plan to keep those data on the Langley Archive data base together with the model results

Author contributions. HV led the preparation of the paper. AP and NR contributed to the chemical analysis of the balloon samples. MVR, HG, AP, JPV, DF, SK, GB organized the balloon flights. FW contributed to the analysis of the COBALD data. HL and BZ performed GEOS-Chem model simulations and assisted with model output analysis. KB analyzed HIMAWARI-8

Competing interests. The authors declare that they have no conflict of interest. 
1 Acknowledgement. HL, TDF, KMB, BZ, and JPV acknowledge funding support from the NASA

2 Atmospheric Composition Modeling and Analysis Program (ACMAP) and the Upper

3 Atmospheric Research Program (UARP). NASA Center for Computational Sciences (NCCS)

4 provided supercomputing resources. The GEOS-Chem model is managed by the Atmospheric

5 Chemistry Modeling Group at Harvard University with support from NASA ACMAP and MAP

6 programs.

7 Financial support. This research has been supported by XXX and the NASA Atmospheric

8 Composition Modeling and Analysis Program (ACMAP).

References:

Abbatt, J. P. D. et al. Solid ammonium sulfate aerosols as ice nuclei: a pathway for cirrus cloud formation. Science 313, 1770-1773 (2006).

Behera, S.N., Sharma, M. Anja, V.P. \& Balasubramanian, R. Ammonia in the atmosphere: a review on emission sources, atmospheric chemistry and deposition on terrestrial bodies. Environ. Sci. Pollut. Res. 20, 8092-8131 (2013). 
1 Bond, T. C., Bhardwaj, E., Dong, R., Jogani, R., Jung, S., Roden, C., et al. (2007). Historical emissions of black and organic carbon aerosol from energy-related combustion, 18502000. Global Biogeochemical Cycles, 21, GB2018. https://doi.org/10.1029/2006GB002840

Brabec, M., Wienhold, F. G., Luo, B. P., Vömel, H., Immler, F., Steiner, P., Hausammann, E., Weers, U., and Peter, T.: Particle backscatter and relative humidity measured across cirrus clouds and comparison with microphysical cirrus modelling, Atmos. Chem. Phys., 12, 9135-9148, https://doi.org/10.5194/acp-12-9135-2012, 2012.

Cziczo et al., 2015.: Hygroscopic and phase separation properties of ammonium sulfate/organic/water ternary solution. Atmos. Chem. Discuss., 15, 6537-6566, 2015. doi:10.5194/acpd-15-6537-2015.

Crutzen, P.J., 1979: The role of $\mathrm{NO}$ and $\mathrm{NO}_{2}$ in the chemistry of the troposphere and stratosphere. Ann. Rev. Earth Planet. Sci., 7, 443-472.

Darmenov, A. and da Silva, A., The Quick Fire Emissions Dataset (QFED): Documentation of versions 2.1, 2.2 and 2.4, NASA Technical Report Series on Global Modeling and Data Assimilation NASA TM-2015-104606, Volume 38, http://gmao.gsfc.nasa.gov/pubs/docs/Darmenov796.pdf, 2015.

Dentener, F.J. \& Crutzen, P.J. A dimensional model of the global Ammonia cycle. J. Atmos. Chem. 19, 331-369 (1994).

Fairlie, T. D., J.-P. Vernier, M. Natarajan, and K. M. Bedka (2014), Dispersion of the Nabro volcanic plume and its relation to the Asian summer monsoon, Atmos. Chem. Phys., 14, 7045-7057, doi:10.5194/acp-14-7045-2014.

Gelaro, R., McCarthy, W., Suárez, M.J., Todling, R., Molod, A., Takacs, L., Randles, C.A., Darmenov, A., Bosilovich, M.G., Reichle, R., Wargan, K., Coy, L., Cullather, R., Draper, C., Akella, S., Buchard, V., Conaty, A., da Silva, A.M., Gu, W., Kim, G.-K., Koster, R., Lucchesi, R., Merkova, D., Nielsen, J.E., Partyka, G., Pawson, S., Putman, W., Rienecker, M., Schubert, S. D., Sienkiewicz, M., Zhao, B., 2017. The Modern-Era Retrospective 
Analysis for Research and Applications, Version 2 (MERRA-2). Journal of Climate, doi:10.1175/JCLI-D-16-0758.1

Guenther, A. B., Jiang, X., Heald, C. L., Sakulyanontvittaya, T., Duhl, T., Emmons, L. K., \& Wang, X. (2012). The Model of Emissions of Gases and Aerosols from Nature version 2.1 (MEGAN2.1): An extended and updated framework for modeling biogenic emissions.

Gu, Y., Liao, H., and Bian, J.: Summertime nitrate aerosol in the upper troposphere and lower stratosphere over the Tibetan Plateau and the South Asian summer monsoon region, Atmos. Chem. Phys., 16, 6641-6663, https://doi.org/10.5194/acp-16-6641-2016, 2016.

Hauglustaine, D.A., Balkanski, Y. \& Schulz, M. A global model simulation of present and future nitrate aerosols and their direct radiative forcing of climate. Atmos. Chem. Phys. 14,

Höpfner, M., Volkamer, R., Grabowski, U., Grutter, M., Orphal, J., Stiller, G., von Clarmann, T.,

Lelieveld, J. et al. The South Asian monsoon: pollution pump and purifier. Science 361, 270-273 30 (2018). and Wetzel, G.: First detection of ammonia $\left(\mathrm{NH}_{3}\right)$ in the Asian summer monsoon upper troposphere, Atmos. Chem. Phys., 16, 14357-14369, https://doi.org/10.5194/acp-1614357-2016, 2016.

Höpfner, M. et al. Ammonium nitrate particles formed in upper troposphere from ground Ammonia sources during Asian monsoons. Nature. Geosc. Vol. 12, 608-612 (Aug, 2019).

Hutchinson, G. E., 1954: The biogeochemistry of the terrestrial atmosphere. The Earth as a Planet, G.P. Kuiper, Ed; The university of Chicago Press, 371-433.

IPCC climate change 2013: The Physical Science Basis (eds Stacker, T.F., et al.Cambridge Univ. Press, 2013).

Kar, J., et al. (2004), Evidence of vertical transport of carbon monoxide from measurements of pollution in the troposphere (MOPITT), Geophys. Res. Lett., 31, L23105, doi:10.1029/2004GL021128. 
Li, M., Zhang, Q., Streets, D. G., He, K. B., Cheng, Y. F., Emmons, L. K., Huo, H., Kang, S. C., Lu, Z., Shao, M., Su, H., Yu, X., and Zhang, Y.: Mapping Asian anthropogenic emissions of non-methane volatile organic compounds to multiple chemical mechanisms, Atmos. Chem. Phys., 14, 5617-5638, https://doi.org/10.5194/acp-14-5617-2014, 2014.

Lightstone J.M., Timothy, B., Onasch., \& Dan Imre.: Deliquescence Efflorescence, and Water Activity in Ammonium nitrate and mixed Ammonium nitrate/succinic acid Microparticles, J. Phys. Chem. A2000, 104, 9337-9346.

Murray, L.T., D.J. Jacob, J.A. Logan, R.C. Hudman, and W.J. Koshak, Optimized regional and interannual variability of lightning in a global chemical transport model constrained by LIS/OTD satellite data, J. Geophus. Res., 117, D20307, 2012.

Olivier, J. G. J., \& Berdowski, J. J. M. (2001). Global emissions sources and sinks. In J. Berdowski, R. Guicherit, \& B. J. Heij (Eds.), The Climate System, (pp. 33-78). Lisse, The Netherlands: A. A. Balkema Publishers/Swets \& Zeitlinger Publishers.

Orbe, C., D. W. Waugh, and P. A. Newman (2015), Air-mass origin in the tropical lower stratosphere: The influence of Asian boundary layer air, Geophys. Res.Lett., 42, 42404248, doi:10.1002/2015GL063937.

Pandit A.K., et al., 16- year climatology of cirrus clouds over a tropical station in southern India using ground and space-based lidar observations. Atmos. Chem. Phys. Discuss., 15, 15791-15830 (2015).

Park, M. et al. Chemical isolation in the Asian monsoon anticyclone observed in Atmospheric Chemistry Experiment ( ACE-FTS) data. Atmos. Chem. Phys. 8, 757-764 (2008).

Park, M., W.J. Randel, A. Gettelman, S. Massie and J. Jiang, Transport above the Asian summer monsoon anticyclone inferred from Aura MLS tracers (2007), J. Geophys. Res., 112, D16309, doi:10.1029/2006JD008294.

Park, R. J., D. J. Jacob, B. D. Field, R. M. Yantosca, and M. Chin, 2004, Natural and transboundary pollution influences on sulfate-nitrate-ammonium aerosols in the United States: Implications for policy, J. Geophys. Res., 109, D15204, doi:10.1029/2003JD004473. 
Park, R. J., D. J. Jacob, M. Chin, and R. V. Martin, Sources of carbonaceous aerosols over the United States and implications for natural visibility, J. Geophys. Res., 108(D12), 4355, doi:10.1029/2002JD003190, 2003.

Pye, H. O. T., Chan, A. W. H., Barkley, M. P., \& Seinfeld, J. H. (2010). Global modeling of organic aerosol: The importance of reactive nitrogen (NOx and NO3). Atmospheric Chemistry and Physics, 10, 11,261-11,276. https://doi.org/10.5194/acp - 10 - 11261 $\underline{2010}$

Ploeger, F., Konopka, P., Walker, K., and Riese, M.: Quantifying pollution transport from the Asian monsoon anticyclone into the lower stratosphere, Atmos. Chem. Phys., 17, 70557066, https://doi.org/10.5194/acp-17-7055-2017, 2017.

Ramanathan, V. and P. J. Crutzen: New Directions: Atmospheric Brown "Clouds". Atmospheric Environment, 37, 4033-4035., (2003).

Randel, W. J., M. Park, L. Emmons, D. Kinnison, P. Bernath, K. A. Walker, C. Boone, and H. Pumphrey (2010), Asian monsoon transport of pollution to the stratosphere, Science, 328, 611-613, doi:10.1126/science.1182274.

Rasch, P.J., Tilmes, S., Turco, R.P., Robock, A., Oman, L., Chen, R.R.: An overview of geoengineering of climate using stratospheric sulphate aerosols, Philos. T. Roy. Soc. A, 366, 4007-4037, doi: 10.1098/rsta. 2008.0131, 2008.

Ridley, D.A., C.L. Heald, and J.M. Prospero, what controls recent changes in African mineral dust across the Atlantic? Atmos. Chem. Phys., 14, 5735-5747, 2014 www.atmos-chemphys.net/14/5735/2014/ doi:10.5194/acp-14-5735-2014.

Rienecker, M.M., et al. 2011, MERRA: NASA's Modern-Era Retrospective Analysis for Research and Applications, J. Climate, Vol. 24, p.3624-3648, DOI: 10.1175 /JCLI-D-11whtxt00015.1.

Santee, M. L. et al. A comprehensive overview of the climatological composition of the Asian summer monsoon Anticyclone based on 10 years of Aura microwave limb sounder measurements. J. Geophys. Res. 122, 5491-5514 (2017). 
1 Solomon, S., et al. (2016), Monsoon circulations and tropical heterogeneous chlorine chemistry in the stratosphere, Geophys. Res. Lett., 43, 12,624-12,633, doi:10.1002/2016GL071778.

Thomason, L. W., and J.-P. Vernier (2013), Improved SAGE II cloud/aerosol categorization and observations of the Asian tropopause aerosol layer: 1989-2005, Atmos. Chem. Phys., 13, 4605-4616, doi:10.5194/acp-13-4605-2013.

Ungermann, J. et al. Observations of PAN and it's confinement in the Asian summer monsoon Anticyclone in high spatial resolution. Atmos. Chem. Phys. 16, 8389-8403 (2016).

Travis, K. R., D. J. Jacob., J. A. Fisher., P. S. Kim., E. A. Marais., L. Zhu, K. Yu., C. C. Miller., R. M. Yantosca., M. P. Sulprizio., A. M. Thompson., P. O. Wennberg., J. D. Crounse., J. M. St. Clair., R. C. Cohen., J. L. Laughner., J. E. Dibb., S. R. Hall, K. Ullmann., G. M. Wolfe., J. A. Neuman., and X. Zhou, Why do models overestimate surface ozone in the Southeast United States, Atmos. Chem. Phys., 16, 13561-13577, doi:10.5194/acp-1613561-2016, 2016.

Vernier, J., T.D. Fairlie, T. Deshler, M. Venkat Ratnam, H. Gadhavi, B.S. Kumar, M. Natarajan, A.K. Pandit, S.T. Akhil Raj, A. Hemanth Kumar, A. Jayaraman, A.K. Singh, N. Rastogi, P.R. Sinha, S. Kumar, S. Tiwari, T. Wegner, N. Baker, D. Vignelles, G. Stenchikov, I. Shevchenko, J. Smith, K. Bedka, A. Kesarkar, V. Singh, J. Bhate, V. Ravikiran, M. Durga Rao, S. Ravindrababu, A. Patel, H. Vernier, F.G. Wienhold, H. Liu, T.N. Knepp, L. Thomason, J. Crawford, L. Ziemba, J. Moore, S. Crumeyrolle, M. Williamson, G. Berthet, F. Jégou, and J. Renard, 2018: BATAL: The Balloon Measurement Campaigns of the Asian Tropopause Aerosol Layer. Bull. Amer. Meteor. Soc., 99, 955973,https://doi.org/10.1175/BAMS-D-17-0014.1

Vernier, J.-P., L. W. Thomason, and J. Kar (2011), CALIPSO detection of an Asian tropopause aerosol layer, Geophys. Res. Lett., 38, L07804, doi:10.1029/2010GL046614.

Vernier, J. -P. ., Fairlie, T. D., Natarajan, M., Wienhold, F. G., Bian, J., Martinsson, B. G., Crumeyrolle, S., Thomason, L. W. and Bedka, K. M. (2015), Increase in upper tropospheric and lower stratospheric aerosol levels and its potential connection with Asian pollution. J. Geophys. Res. Atmos., 120: 1608-1619. doi: 10.1002/2014JD022372. 
1 Voigt, C., et al. Dec. 2000. 'Nitric Acid Trihydrate (NAT) in Polar Stratospheric Clouds'. Sci.

2 (5497): 1756-8.

3 Von Liebig, J ; 1827 : Une note sur la nitrification. Ann. Chem. Phys., 35, 329-333.

4 Yevich, R., \& Logan, J. A. (2003). An assessment of biofuel uses and burning of agricultural waste 5 in the developing world. Global Biogeochemical Cycles, 17(4), 1095. $6 \quad$ https://doi.org/10.1029/2002GB001952

$7 \mathrm{Yu}, \mathrm{P}$. et al. Efficient transport of tropospheric aerosol into the stratosphere via the Asian summer monsoon anticyclone. Proc. Natl. Acad. Sci. USA 114, 6972-6977 (2017).

9 Yu, P., Toon, O.B., Neely, R.R., Martinsoon, B.G. \& Brenninkmeijer, C.A.M. Composition and 10 physical properties of the Asian tropopause aerosol layer and the North American tropospheric aerosol layer. Geophys. Res. Lett. 42, 2540-2546 (2015). 

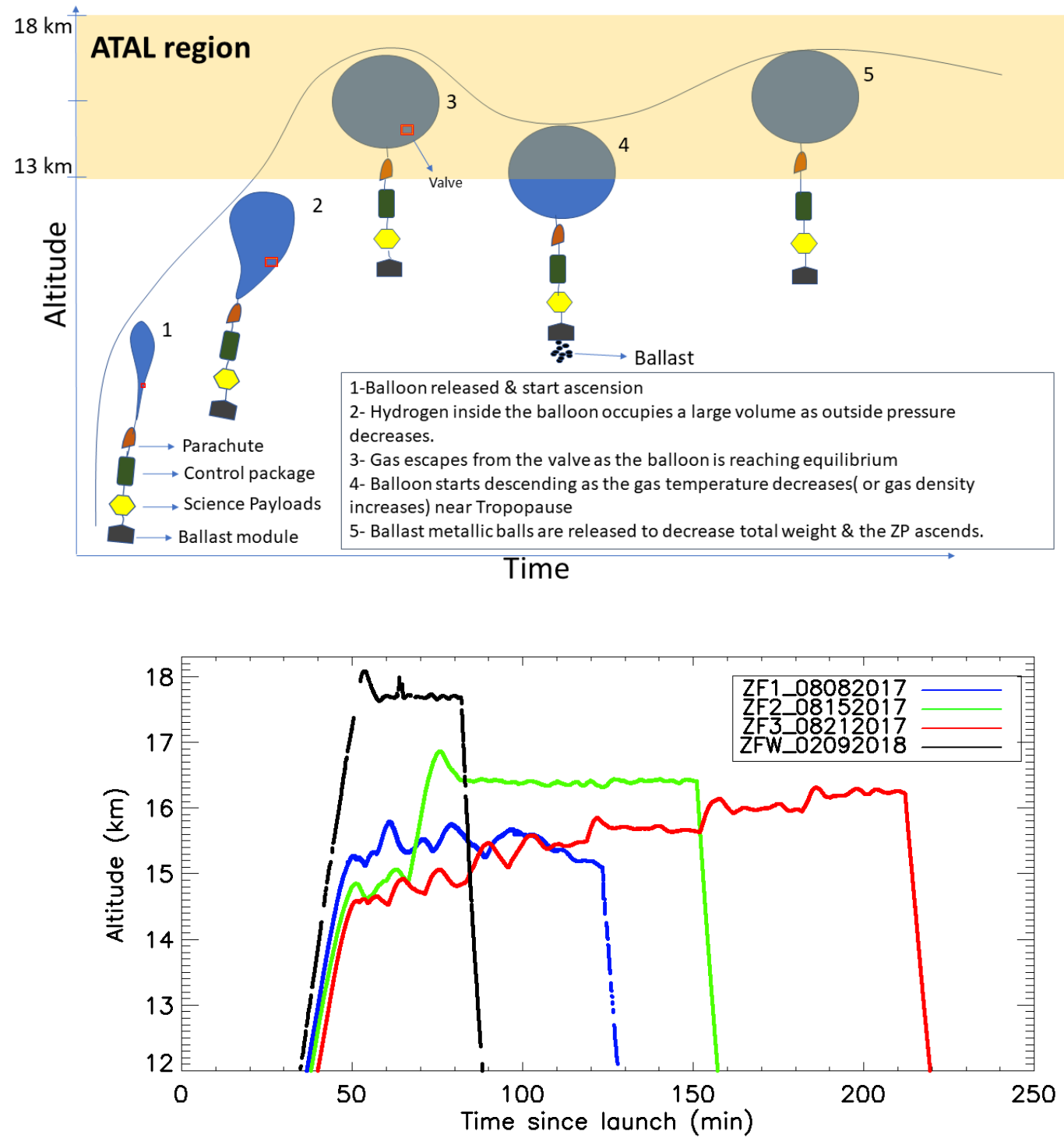

3

4 Figure 1. (Top). Schematic diagram of the zero-pressure flight concept. (Bottom) Time-height

5 curves of the GPS altitudes of the 3 zero-pressure flights during summer 2017, in comparison

6 with that of winter 2018, launched from TIFR-BF, Hyderabad, India. 

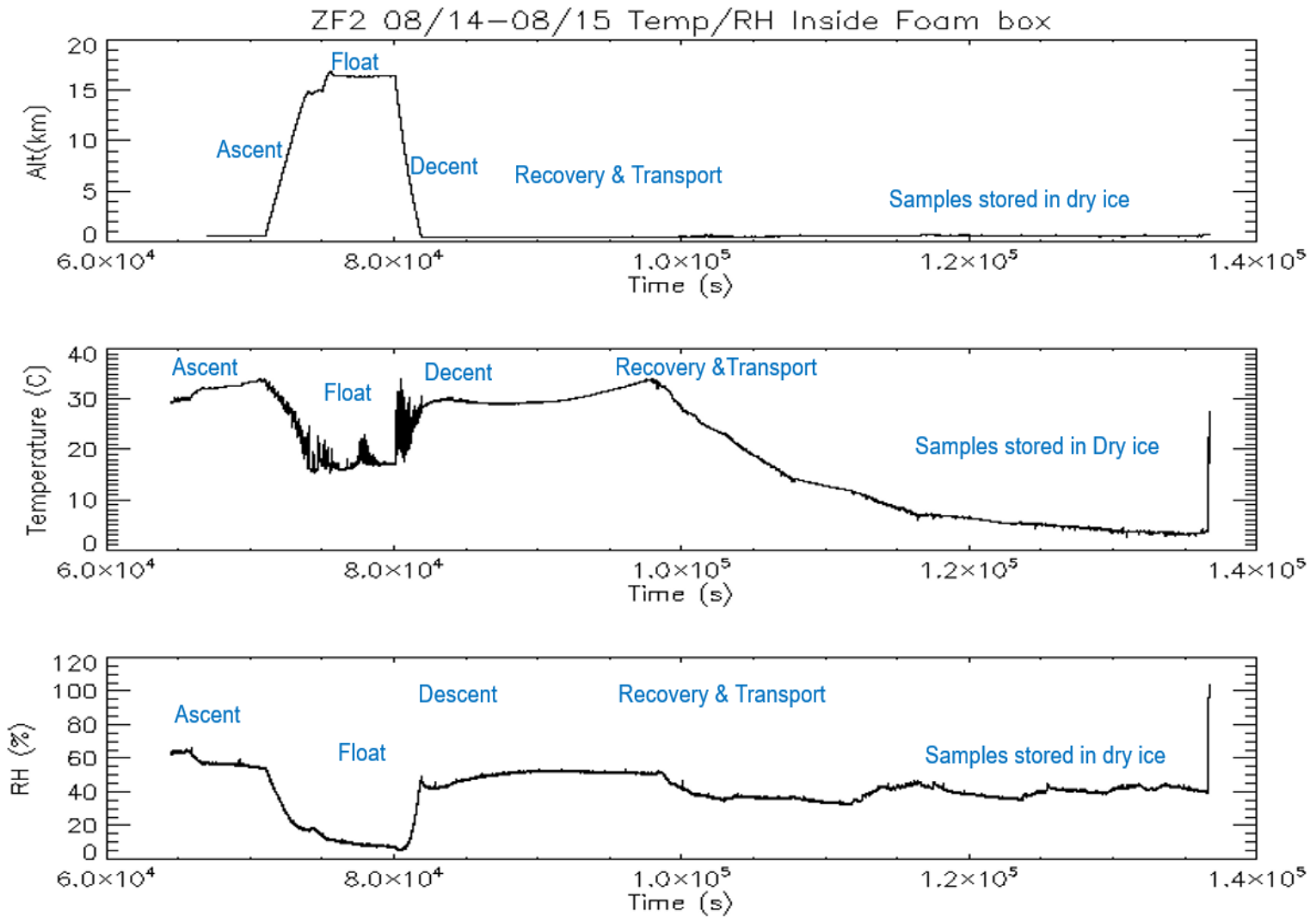

1

2 Figure 2. Time series of the Altitude, Temperature, and Relative humidity profiles of the

3 samples inside the foam box during ZF2 flight.

4

5

6

7 


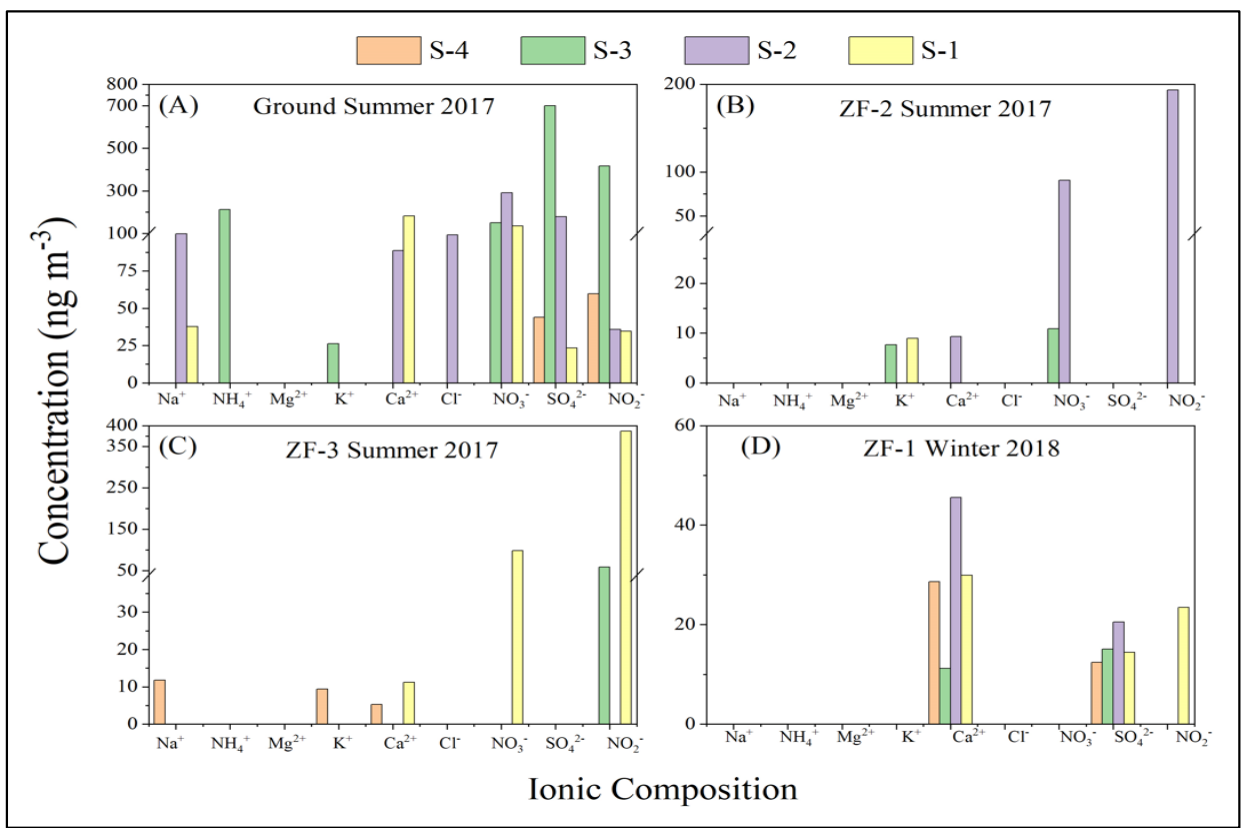

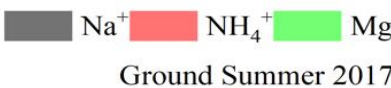

(A)

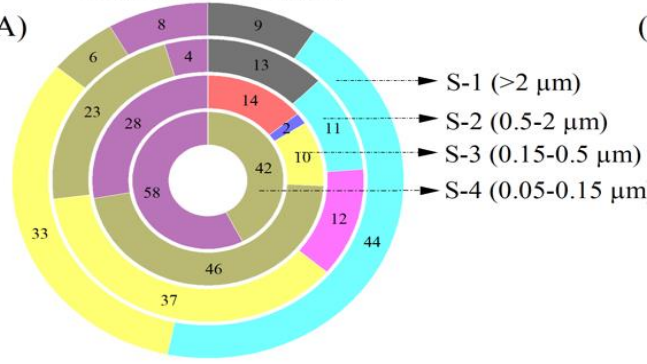

ZF-3 Summer 2017

(C)

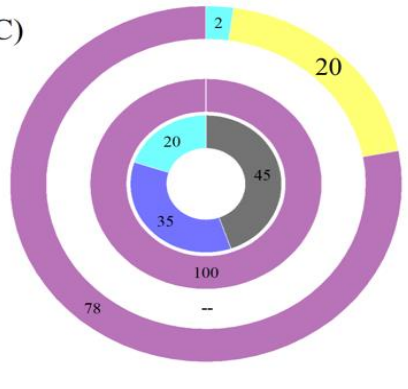

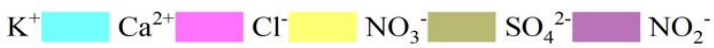

ZF-2 Summer 2017

(B)

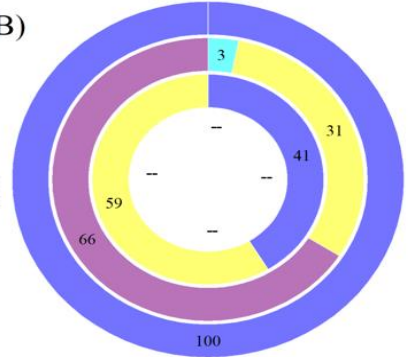

ZF-1 Winter 2018

(D)

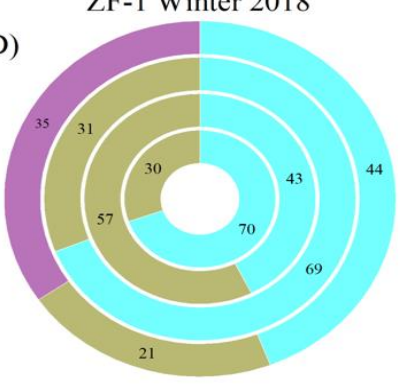

3 Figure 3. Results from the analysis of inorganic aerosol. (Top) Aerosol ionic composition of the 4 filters collected on (A) the ground, during (B) ZF2 and (C) ZF3 of Summer 2017, and (D) ZF1 in 
https://doi.org/10.5194/acp-2021-910

Preprint. Discussion started: 3 December 2021

(c) Author(s) 2021. CC BY 4.0 License.

1 Winter 2018. (Bottom) Percentage distribution of individual ions. S1 to S4 indicates the four

2 stages of the impactor. The size cut off is 2, 0.5, 0.15 and 0.05 micron for S1, S2, S3 and S4,

3 respectively.

4

5

6

7

8

9

10

11

12

13

14

15 
1
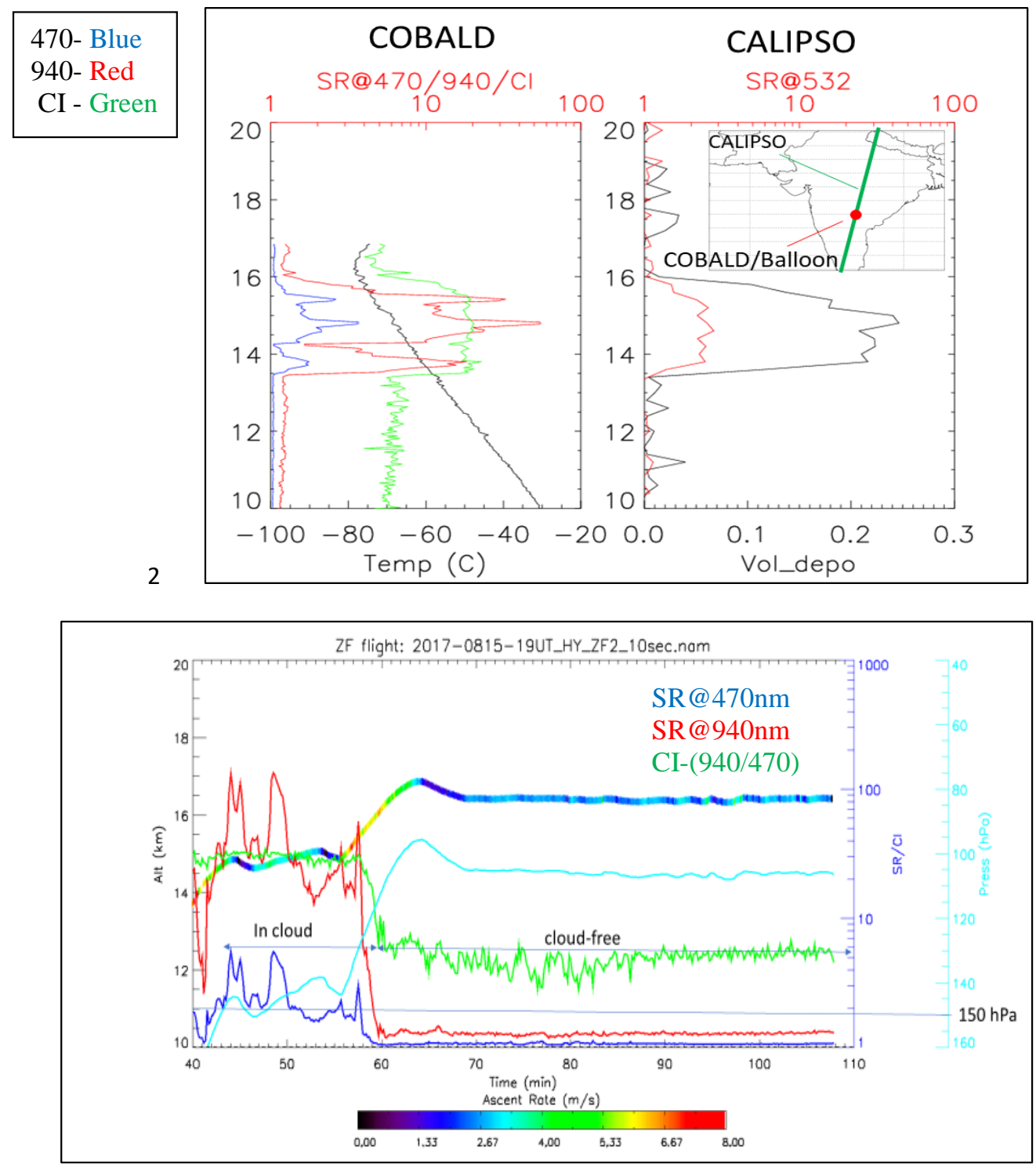

4

5 Figure 4. (Top) COBALD balloon In Situ and CALIOP Satellite Scattering Ratios (SR), volume 6 depolarization and Color Index (CI) profiles collocated in time and space (within $20 \mathrm{~km}$ and $1 \mathrm{~h}$ ) 7 on August, $15^{\text {th }}$ at 19 UT. (Bottom) Time series along ZF2 of Scattering Ratios (SR) at $940 \mathrm{~nm}$ 8 and $470 \mathrm{~nm}$ from COBALD and GPS altitude (colored with ascent rate) and measured pressure 9 from the Imet radiosonde. 


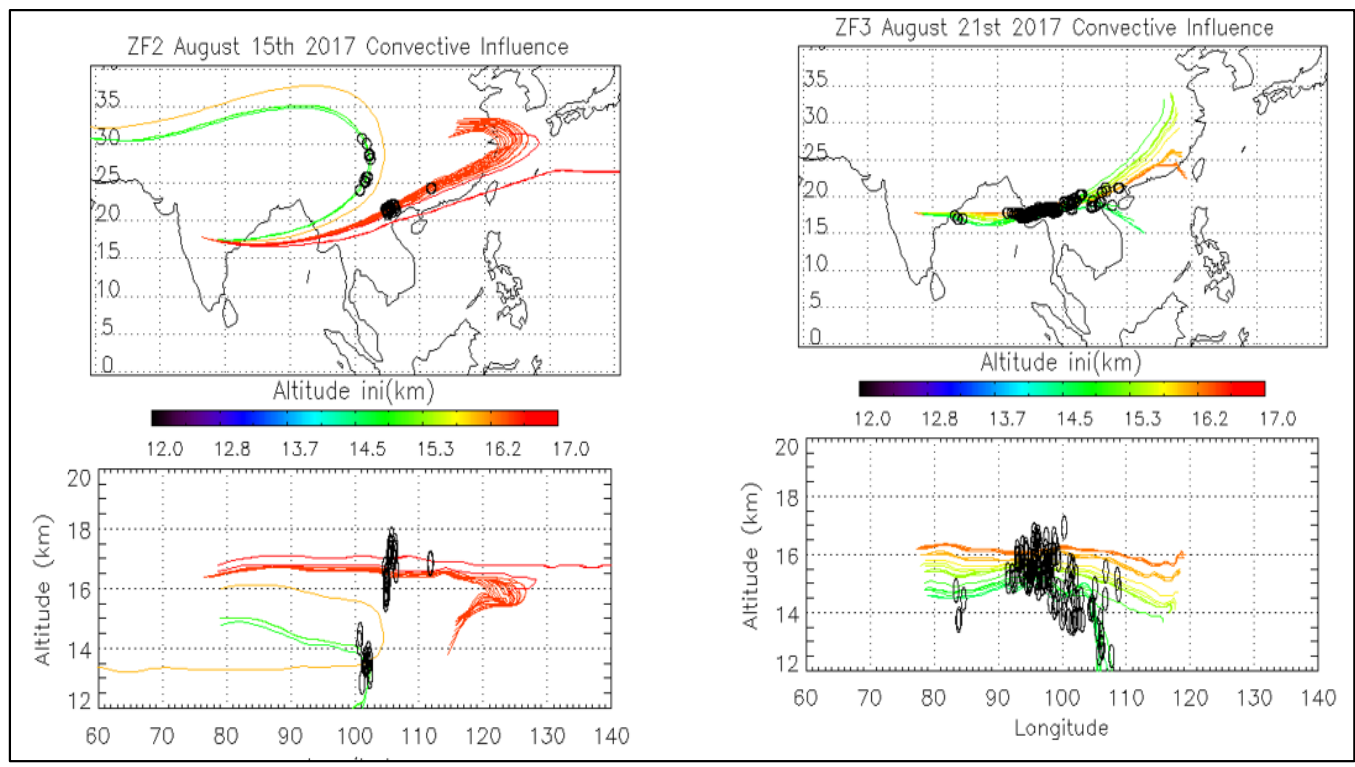

3 Figure 5. Back-trajectories initialized from ZF2 (08/15) and ZF3 (08/21) measurements between

$4 \quad 150 \mathrm{hPa}$ and $70 \mathrm{hPa}$. Black dots along the trajectories are the position of convective systems

5 intersecting air masses sampled during the balloon flight. 

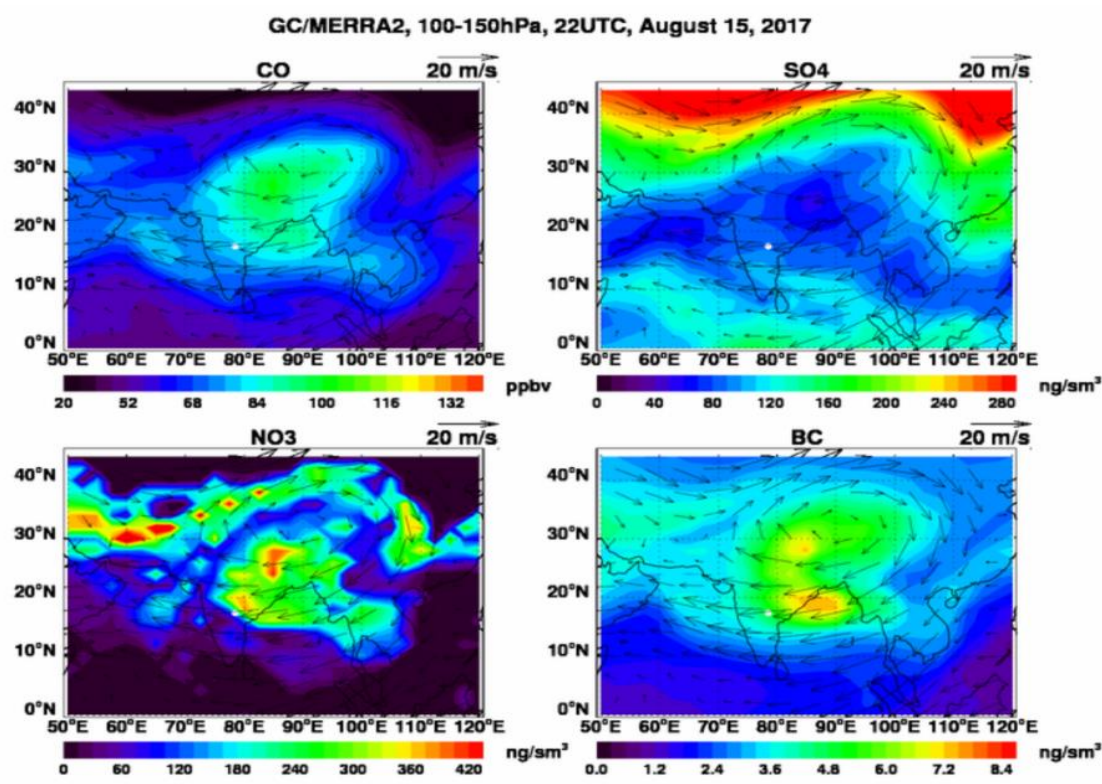

GC/MERRA2, 100-150hPa, 22UTC, August 21, 2017

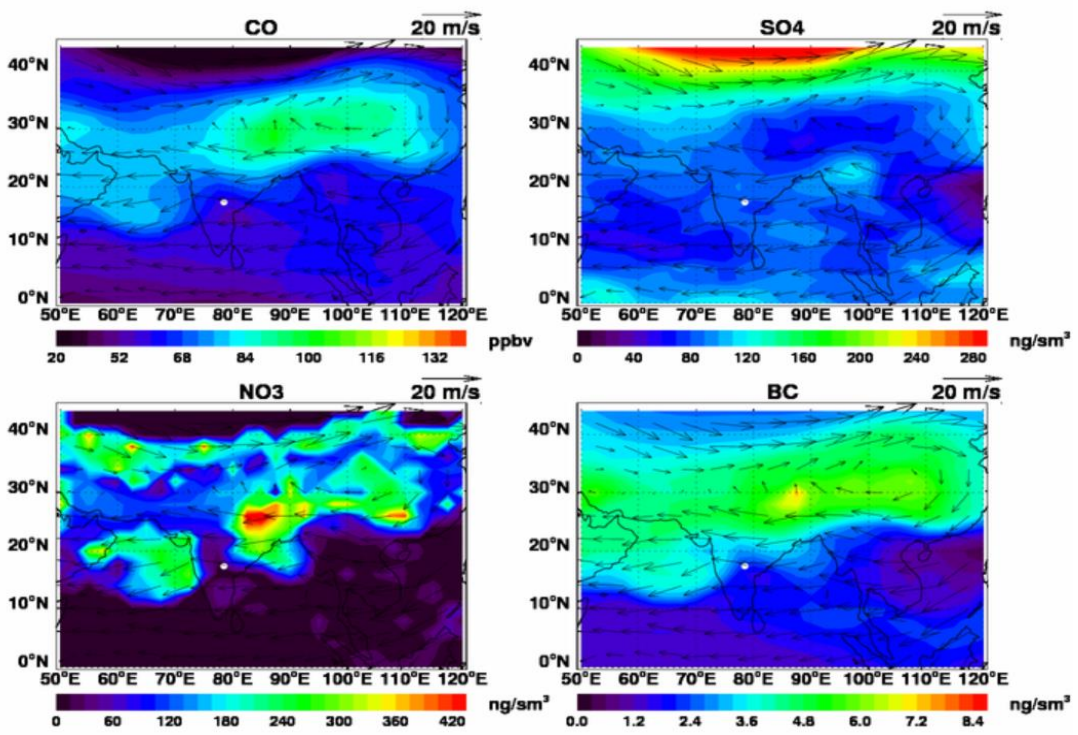

5 Figure 6. GEOS-Chem model-simulated carbon monoxide $(\mathrm{CO}, \mathrm{ppbv})$, nitrate $\left(\mathrm{NO}_{3}{ }^{-}, \mathrm{ng} / \mathrm{m}^{3}\right.$ $6 \mathrm{STP})$, sulfate $\left(\mathrm{SO}_{4}{ }^{2-}, \mathrm{ng} / \mathrm{m}^{3} \mathrm{STP}\right)$, and black carbon $\left(\mathrm{BC}, \mathrm{ng} / \mathrm{m}^{3} \mathrm{STP}\right)$ concentrations averaged 7 over 100-150hPa at 22UTC, August 15 ${ }^{\text {th }}$ (top panels), and August 21 ${ }^{\text {st }}$ (bottom panels), 2017. 
https://doi.org/10.5194/acp-2021-910

Preprint. Discussion started: 3 December 2021

(c) Author(s) 2021. CC BY 4.0 License.

1 Standard temperature and pressure (STP) are 298K and 1013.25hPa, respectively. Arrows denote

2 wind direction while the white dot indicates sampling location, Hyderabad, India.

3

4

6

7

9

10

11

12

14

15

17

18

19

20

22

23

24

26

27

28

29

30

31
32

33

34

35

36

37
38

39

40

41

42

43

44

45
46 


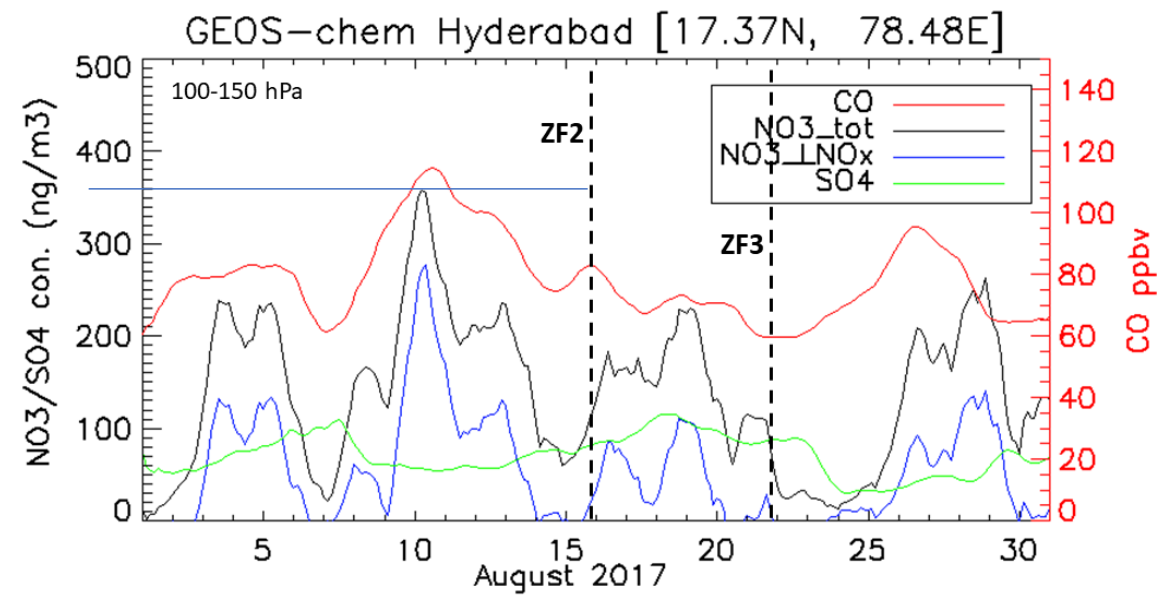

1

2 Figure 7. Time series of simulated 3-hourly $\mathrm{CO}, \mathrm{SO}_{4}{ }^{2-}$, and $\mathrm{NO}_{3}{ }^{-}$concentrations averaged over

$3 \quad 100-150 \mathrm{hPa}$ at Hyderabad during the ZF2 and ZF3 flights on $15^{\text {th }}$ Aug. \& $21^{\text {st }}$ Aug., 2017. Also

4 shown are concentrations of $\mathrm{NO}_{3}{ }^{-}$due to lightning NOx emissions (NO3_LNOx). See text for 5 details.

7 


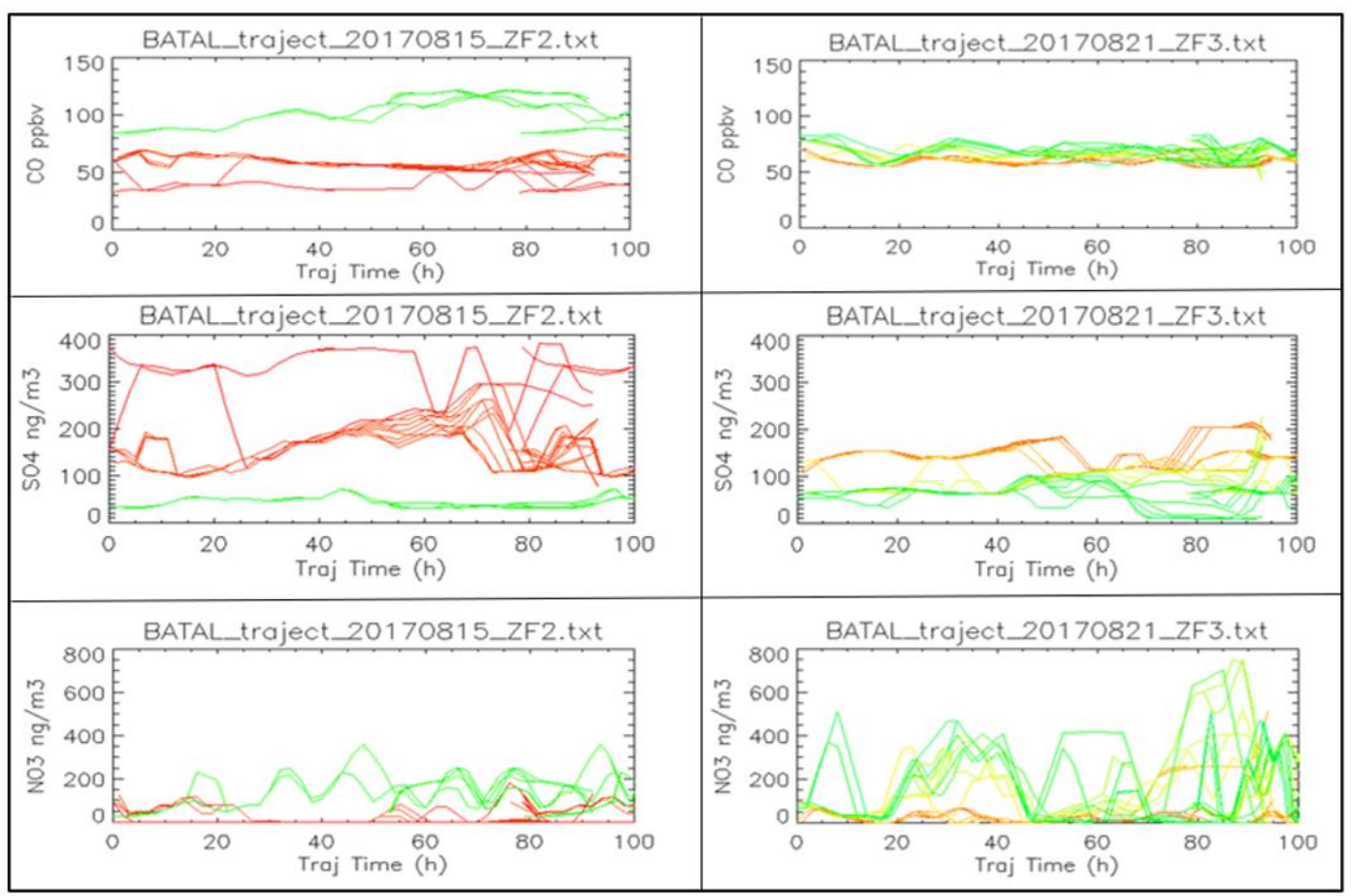

1

2

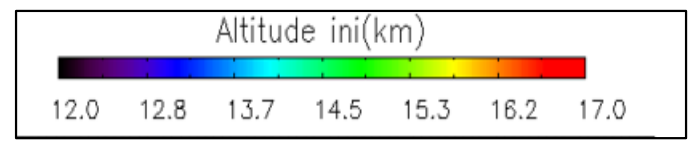

3 Figure. 8. GEOS-Chem model-simulated $\mathrm{CO}, \mathrm{SO}_{4}{ }^{2-}$, and $\mathrm{NO}_{3}{ }^{-}$concentrations extracted along the 4 trajectory lines during flights ZF2 and ZF3 (Fig. 5).

5

6

7

8 